\title{
1. EU constitutionalism, crisis and the security of the European project
}

\section{INTRODUCTION}

A thorough analysis of the nature of the EU polity and its grounds of justification -if any-would require us to take stock of a considerable amount of studies on this topic, which testifies to its ongoing relevance and attraction. This chapter, however, does not intend to offer an ambitiously exhaustive review of the academic reflections on the EU, nor does it content itself with merely giving an account of the main points of contention. Its purpose is, rather, to set the scene for the deeper inquiry that will be attempted in the following chapters. In this sense, it provides an interpretative scheme which can be employed to understand not only what sort of creature emerges from the accounts of the early years and of more recent times, but also the epistemological reasons behind those accounts. It will thus hopefully begin to be clear to the reader that a few fundamental questions need to be addressed urgently, namely: (a) what paradigms are available to those who are eager to delve deeply into the rationale of European integration; (b) how some of the most recent developments should be conceptualised; (c) what is the relationship between EU constitutionalism and crisis and whether the constitutional vocabulary still possesses sufficient explanatory force. An analysis of the main paradigms of European integration involves an overview of the most popular theories that have dominated the debate in academic circles from the outset. This overview is very helpful to reflect not only on the progress of the European project, but on the claims put forward by EU law scholars.

It will be argued that EU constitutionalism is driven by the metarationale of security, which informs simultaneously the process of transformation of the EU polity, the practices and institutional arrangements that characterize it, and the literature on EU integration, regardless of the disciplinary perspective that is taken. This should prompt us to critically examine whether the languages of security and crisis, which are often intertwined, provide a useful toolbox of concepts or, instead, 
constrain our vision. Generally, works on security and crisis focus either on crisis management and policy making, ${ }^{1}$ or on various facets of national security, ${ }^{2}$ on the relationship between securitization and identity, ${ }^{3}$ or security's public order dimension in international law. ${ }^{4}$ This book aims to adopt a different perspective, one that looks at security and crisis from within law-i.e. at the meta-constitutional significance of their interplay. Security, whose essential features are existential, lies at the heart of Europe's constitutional identity. It is a fundamental rationale upon which the European liberal project is founded. In this sense, the approach adopted in this book is also different from Tuori's idea of 'security constitution', ${ }^{5}$ because it does not look at security as a sectorial aspect of the EU as a legal order and as a polity, but as an overarching conceptualization.

As will be shown in the next chapters, the security meta-rationale reveals itself through two crucial discourses of power: security in the strict sense, embracing both internal and external security, and fundamental rights. The evolution of these ambiguous, contradictory discourses goes hand in hand with the evolution of discursive constituent power.

During its long, for many reasons surprising evolution, the EU has turned into a fully-fledged legal system, displaying a degree of autonomy that is unknown to other transnational processes of integration. It possesses its own norms, principles, institutions which respond, at least in part, to a logic that is separate from and overlapping with the domestic legal framework. After all, principles such as subsidiarity, proportionality,

1 N. Bremberg, Diplomacy and Security Community-Building - EU Crisis Management in the Western Mediterranean (Routledge 2016); F. Tassinari, 'The disintegration of European Security: Lessons from the Refugee Crisis' (2016) 6 (2) PRISM 71; AAVV, Notions of Security: Shifting Concepts and Perspectives (The Hague: COT Institute for Safety, Security and Crisis Management, 2007).

2 J. Richards, A Guide to National Security: Threats, Responses and Strategies (OUP 2012); H. K. Koh, The National Security Constitution - Sharing Power After the Iran-Contra Affair (Yale University Press 1990).

3 J. P. Burgess, The Ethical Subject of Security - Geopolitical Reason and the Threat Against Europe (Routledge 2011); O. Waever, 'European Security Identities' (1996) 34 Journal of Common Market Studies 103.

4 J. Kurtz, 'Adjudging the Exceptional at International Investment Law: Security, Public Order and Financial Crisis' (2010) International and Comparative Law Quarterly 325.

5 K. Tuori, European Constitutionalism (Cambridge University Press 2015) 269; K. Tuori, 'A European Security Constitution?' in M. Fichera, J. Kremer (eds.) Law and Security in Europe: Reconsidering the Security Constitution (Intersentia 2013) 39. 
implied powers, and the doctrines of direct effect and primacy, have been crucial in creating an institutional landscape that has successfully become an integral part of the Member States' legal systems. EU agencies, mechanisms of evaluation and cooperation, administrative and regulatory schemes, are actively involved in policy-making. However, ever since the significant breakthrough of the Treaty of Maastricht, the growing political ambitions of the EU have immediately posed important dilemmas, which could not be solved by adopting the traditional categories of State law. Inevitably, as the EU increasingly put forward its claim as autonomous polity, it was also called upon to live up to the rule of law standards of the States that composed it-and to exhibit democratic credentials that seemed simultaneously necessary and impossible to achieve. The recent crises have merely exacerbated the tensions deriving from the above challenges and raised new doubts over the viability of the European project. Once again, the shaky foundations of the EU as a polity are questioned. Are we bound to witness the final hour of the European project as we know it? After an overview of the paradigms of European integration, this chapter sketches briefly the multiple dimensions of the security of the European project.

\section{SOUL SEARCHING}

These are troubled times for any transnational European apologetics. Not only is the European liberal project in a deep state of crisis, but it looks unable to provide uncontroversial solutions to the continuous demands that originate from exceptional events challenging its raison d'être. Over the last seven to eight years, all crises that have affected the European Union (EU), from the financial crisis, to the refugee and terrorism crisis, the rule of law crisis, the constitutional identity crisis and Brexit crisis, have struck at the heart of EU constitutionalism. What seemed to be a promising future for European integration in the first decade of this century-however that future might have been imagined-has turned into a desolate land and a dystopic idea threatening the social and political order both at the national and EU level.

Soul-searching and critical reflection are, of course, once again the focus of European debates, policy summits and speeches. ${ }^{6}$ Yet, the

6 See e.g. J. C. Juncker, 'State of the Union Address 2016: Towards a Better Europe - a Europe that protects, empowers and defends', Strasbourg, 14 September 2016: 'Let us all be very honest in our diagnosis. Our European Union is, at least in part, in an existential crisis'. 
intensity and number of shockwaves that have affected the European project in these recent years should be welcomed as an opportunity for a deeper analysis of the process of European integration, one that digs beneath the veneer of triumphalism and complacency, which have dominated much of the self-descriptive statements by the EU institutions over the years. ${ }^{7}$

For a relatively long period, European constitutionalism has provided some answers to the challenges posed by repeated calls to comply with democratic legitimacy standards: it has been thus held that the EU's lack of constitutional authority in the sense of pouvoir constituant does not rule out the existence of a normative authority exercised over national political communities. ${ }^{8}$ One of the main predicaments of the ambitious European liberal project, however, has been that its highly complex nature has made it very difficult to find for the EU a commonly agreed definition encompassing the multiple dimensions of European integration. Approaches have developed along a vertical axis (depending on the extent to which they would be prepared to identify supranational, or even federal features in the EU) and along a horizontal axis (depending on the degree of democracy they would observe or deem necessary in a supranational constellation). The nuances, perspectives and critical analysis proposed by each definition are influenced inevitably not only by individual worldviews and personal experience, but also by the disciplinary context from which they originate and the associated epistemological biases. Thus, for example, most traditional constitutional lawyers, international relations theorists and international lawyers-while not necessarily departing from the same premises-tend to emphasise, from either

7 See e.g. more recently Brussels European Council Conclusions, 27 June 2014, EUCO 79/14, p. 7: 'Recent signs of economic recovery are encouraging and demonstrate that the joint efforts of member States and EU institutions are bearing fruit'; Communication from the Commission 'The EU Justice Agenda for 2020 - Strengthening Trust, Mobility and Growth within the Union', Strasbourg, 11 March 2014, COM (2014) 144 final, p. 1: 'Over the last 15 years, on the basis of the Treaties of Maastricht, Amsterdam and Nice, the EU has progressively developed a European area of justice and an EU justice policy'.

8 M. P. Maduro, 'The importance of being called a constitution: Constitutional authority and the authority of constitutionalism' (2005) 3 ICON 332, 352-53. For Maduro, the polity-building character of the project of European integration is conveyed by a combination of constitutional authority delegated by the national political communities and a form of incremental and reflexive constitutionalism' based on deliberative decision-making. In this sense, 'Europe does not lack a people so much as it lacks a genuine exercise of constitutional power by that people'. 
a descriptive or a normative standpoint or both, the prevalence of the Member States' will, whereas many human rights lawyers and EU lawyers claim it is increasingly possible to detect a federal set of autonomous powers and institutions in the emerging polity. Ultimately, however, EU constitutionalism is often vulnerable to the temptation of legal determinism. It is thus necessary to explain why and how this happens, and how EU constitutionalism should be reconceived.

\section{PARADIGMS OF EUROPEAN INTEGRATION}

As noted, the EU has been depicted from many perspectives. What is interesting about the various approaches adopted by academic commentators, is the commitment to the idea that, for better or worse, some form of transnational cooperation is beneficial and, in a sense, inevitable. At one end of the spectrum are those views that argue that States' authority, in one way or another, still carries a significant weight in the architecture of the EU. These views range from functionalist models (which, for example, argue that the core of EU policy making is represented by regulation, pursuing both negative integration-i.e. the removal of obstacles to free trade-and positive integration measures-focused mostly on risk regulation $)^{9}$ to those administrative governance models which do not relinquish a normative commitment to national representative government as the privileged source of constitutional legitimacy. ${ }^{10}$ These configurations are not conceptually far from the classic 'no demos thesis', which has consistently held that, regardless of how we wish to label the European project, the latter is tainted by the lack of a people as a source of constituent power. ${ }^{11}$ Whilst recognizing that a large part of domestic internal affairs cannot be regulated autonomously and effectively at the State level, these conceptualisations are keen on emphasizing the either completely absent or weak collective identity as well as the not fully established EU citizens' capacity for transnational discourse. ${ }^{12}$ As

9 G. Majone, 'The rise of the regulatory state in Europe' (1994) 17 West European Politics 77.

10 P. Lindseth, Power and Legitimacy - Reconciling Europe and the NationState (OUP 2010) 263.

11 D. Grimm, 'Does Europe Need a Constitution?' (1995) 1 European Law Journal 282.

12 D. Grimm, ibid. 297; D. Grimm, 'Defending Sovereign Statehood Against Transforming the Union into a State' (2009) 5 European Constitutional Law Review 353. 
some models, most notably the so-called 'regulatory model' of European integration, claim that the delegation of narrowly circumscribed economic tasks to the supranational level fully justifies the existent democratic deficit (at the cost of depoliticizing European policy-making), ${ }^{13}$ the common argument is that only a simultaneous political mobilization in favor of greater integration and cultural attunement would allow for a decisive move from the field of administrative governance to that of constitutionalism proper. ${ }^{14}$ In a similar vein, those who are inclined to label the EU as an 'entity that exercises delegated powers without much discretion, and does so in the public interest', i.e. as a special international organization with distinctive strategic interests and objectives, prefer to avoid employing the constitutional or federalist vocabulary. ${ }^{15}$ The idea that EU law has not yet achieved the status of an autonomous category, distinct from international law (but might achieve this status in a distant future), is not undermined, from this perspective, by the existence of the doctrines of primacy and direct effect. Despite their undeniable peculiarities, the roots of both doctrines can be traced in consolidated international law principles, such as pacta sunt servanda and direct applicability, and, in contrast to federal systems, neither the autonomous validity of EU law nor the supreme legal authority of the Treaties are fully accepted by most domestic courts and political institutions. ${ }^{16}$ Similarly, across the years, the realist school of international relations, as well as rational choice, intergovernmentalist, methodological individualism and sociological approaches, have often resisted the idea

13 G. Majone, 'Europe's Democratic Deficit: the Question of Standards' (1998) 4 European Law Journal 5.

14 See e.g. P. Lindseth, supra 269. Elsewhere (p. 265), the author qualifies the autonomous legitimacy of European governance as 'weak' compared to the legitimacy of national governance and describes it as a system of 'polycentric constitutionalism', as opposed to the incorrect labels of 'constitutional pluralism' and 'multilevel constitutionalism'.

15 J. Klabbers, 'Sui Generis? The European Union as an International Organization' in D. Patterson, A. Södersten (eds.) A Companion to European Union Law and International Law (Wiley 2016) 3, 10-11. Klabbers adds that the peculiar features of the EU should prompt us to amend the very concept of international organization.

16 B. de Witte, 'Rules of Change in International Law: How Special is the European Community?' (1994) 25 Netherlands Yearbook of International Law 299, 331; T. Hartley, 'International Law and the Law of the European Union - A Reassessment' (2001) 72 British Yearbook of International Law 1; B. de Witte, 'Direct effect, primacy, and the nature of the legal order' in P. Craig, G. de Búrca (eds.) The Evolution of EU Law (OUP 2011 2nd edn) 323, 361-62. 
that State sovereignty has been significantly affected by institutional processes of integration. ${ }^{17}$

While one may share at least some of the doubts raised on the configurability of an EU-wide demos, the overall feeling is that Statecentric approaches, however conceived, fail to capture the constitutional character of the self-justifying moves made by the Court of Justice of the European Union (CJEU), the national courts and other European institutions, such as the European Commission. While the latter has sometimes, admittedly, employed the vocabulary of international organisations, especially during the negotiations on the Draft Articles on the Responsibility of International Organisations, it has always been keen on pointing out the unique characteristics of the EU, setting it apart from any other example in the contemporary legal-political landscape. ${ }^{18}$ Similarly, the CJEU has often on the one hand reiterated its classic formula of 'EU as autonomous legal order' having a 'constitutional charter based on the rule of law', and on the other hand never explicitly denied EU law's international legal roots. ${ }^{19}$ We will come back to this aspect later in this work.

17 S. Hoffmann, 'Obstinate or obsolete? The Fate of the Nation State in Western Europe' (1966) 95 Daedalus 862, 909 ('Not only is there no general will of a European people because there is as of now no European people, but the institutions that could gradually (and theoretically) shape the separate nations into one people are not the most likely to do so'); P. Taylor, 'British Sovereignty and the European Community: What is At Risk?' (1991) 20 Millennium: Journal of International Studies 73; M. Mann, 'Nation States in Europe and Other Continents: Diversifying, Developing, not Dying' (1993) 122 Daedalus 115; T. Schilling, 'The Autonomy of the Community Legal Order: An Analysis of Possible Foundations' (1996) 37 Harvard International Law Journal 389 (and the objections in J. Weiler, U. Haltern, 'The Autonomy of the Community Legal Order: Through the Looking Glass' (1996) 37 Harvard International Law Journal 411).

18 UN GA A/CN.4/637, 14 February 2011, p. 7: 'a regional (economic) integration organization'; UN GA A/CN.4/593, 31 March 2008, p. 4: 'the European Commission expresses some concerns as to the feasibility of subsuming all international organisations under the terms of this one draft in the light of the highly diverse nature of international organisations, of which the European Community is itself an example'.

19 Joined Cases C-402/05 P and C-415/05 P Kadi and Al-Barakaat International Foundation v. Council and Commission EU:C:2013:518, para. 285; Opinion 1/09 EU:C:2011:123, paras 65-70; Opinion 1/91 EU:C:1991:490, para. 21; Case 294/83 Parti écologiste 'Les Verts' v. European Parliament EU:C:1986:166, para. 23. As well known, from Case 26/62 Van Gend en Loos v. Nederlandse Administratie der Belastingen ECLI:EU:C:1963:1 to Case 6/64 
Be that as it may, as the EU resists categorization into classic international law paradigms, some scholars who are versed both in international relations and public law studies have made considerable theoretical efforts to convey its so-called sui generis nature. This group of theories depicts the EU as, for example, a 'polycentric community'whose main achievements have been the empowerment of the citizen and the gradual institutionalization of supranational judicial practices ${ }^{20}$ —or a 'self-contained regime'. ${ }^{21}$ However, for all their sophistication, these attempts do not offer a clear-cut, self-standing definition of what the EU ultimately is and sometimes contradict each other when they employ the same term to develop different approaches. For example, while some scholars seemingly claim that the EU goes beyond the logic of inter-State reciprocity, ${ }^{22}$ others do not rule out the application of public international law principles (especially State responsibility) as a last resort, thus falling back on the 'international organisation' label. ${ }^{23}$ In addition, some definitions employed in the field of international relations (such as 'market power', 'divided power', or 'small power'), while pinpointing some important features of the EU's projection on the global scene, do not provide a comprehensive picture of the legal and political implications of the creation of a machinery that at the same time challenges traditional

Costa v. ENEL ECLI:EU:C:1964:66 and Case 106/77 Amministrazione delle finanze dello Stato $v$. Simmenthal ECLI:EU:C:1978:49, references to international law, while present at the onset, have been gradually dropped by the Court.

20 M. Wind, Sovereignty and European Integration: Towards a PostHobbesian Order (Palgrave 2001) 12-13, 83-103, 189-93. The term 'polycentric community' seems different from Lindseth's concept of 'polycentric constitutionalism' (see above, fn 9), because it endorses constitutional pluralism. See also M. Wind, 'The European Union as a polycentric polity: returning to a neomedieval Europe?' in J. Weiler, M. Wind (eds.) European Constitutionalism Beyond the State (CUP 2003) 103.

21 W. Phelan, 'What is Sui Generis about the European Union? Costly International Cooperation in a Self-Contained Regime' (2012) 14 International Studies Review 367.

22 Ibid.

23 B. Simma, 'Self-Contained Regimes' (1985) 16 Netherlands Yearbook of International Law 112; G. Conway, 'Breaches of EC Law and the International Responsibility of Member States' (2002) 13 European Journal of International Law 679; B. Simma, D. Pulkowski, 'Of Planets and the Universe: Self-Contained Regimes in International Law' (2006) 17 European Journal of International Law $483,516-19$. 
Westphalian categories and relies on their factual support both for its existence and justification. ${ }^{24}$

At the other end of the spectrum, lawyers and political scientists alike employ the rich vocabulary of federalism to explain and/or justify the progressive transfer of sovereign powers from the national to the EU level. This debate dates back to the time neo-functionalists maintained that supranational federalized statehood, or a similar arrangement, would be achieved gradually by the European governance's virtues of instrumental rationality and functional spill-over. ${ }^{25}$ This mind-frame has been expressed by its proponents in ever subtler and more refined ways. Thus, while recognizing the awkwardness of applying to the EU all the standards of a federal State, it has been increasingly argued over the years that, by relinquishing the ideas of absolute and undivided sovereignty and unitary constituent power, we should be able to identify a combination of international law and national law elements, and, as a result, define the EU as a sort of 'federation of States'. ${ }^{26}$ The EU would stand out as a coherent legal and political order, in which dual sovereignty is already operative-on the one hand, the national apparatus and the organs that represent the Member States in the EU decision-making process, i.e. the Council, the European Council and the national Parliaments, and on the other hand, the European Commission and the European Parliament as the organs that represent the EU. No priority is conferred on either source of authority. To be sure, 'federal' features could be traced even in the European Coal and Steel and Community (ECSC), the predecessor of the EC/EU, and later in the first studies on European integration. ${ }^{27}$ Yet, insisting on the federalisation of the EC/EU has progressively become easier, as a result of the ever more pronounced

24 C. Wagnsson, 'Divided Power Europe: normative divergences among the EU big three' (2010) 17 Journal of European Public Policy 1089; A. Toje, 'The European Union as a Small Power' (2011) 49 Journal of Common Market Studies 43; C. Damro, 'Market Power Europe' (2012) 19 Journal of European Public Policy 682.

25 See e.g. L. Hooghe (ed.) Cohesion Policy and European Integration: Building Multi-Level Governance (OUP 1996).

26 R. Schütze, "On "federal" ground: the European Union as an (inter) national phenomenon' (2009) 46 Common Market Law Review 1069. As is well known, the German Constitutional Court uses instead the term Staatenverbund (compound of States): BVerfGE 89, 155 (Maastricht)-thus reaffirming the sovereign will of States.

27 E. Haas, The Uniting of Europe (University of Notre Dame Press 2004 [1958]) 38-59 (applying a neo-functionalist scheme to the ECSC); P. Pescatore, 
transfer of national competences to the European institutions and agencies, ${ }^{28}$ and the expansive reading of the Charter of Fundamental Rights (CFR), which has at the same time raised concerns and support. ${ }^{29}$

Federalist theories are particularly intriguing, especially when they draw comparisons between the US and EU experiments, which, while taking place in different historical and cultural contexts, bear some similarities. ${ }^{30}$ However, those theories are not satisfactory for at least three reasons. ${ }^{31}$ First, they do not fully conceptualise the real nature and effects of the overlap between national and international law and simply refer to a combination of these two legal spheres as distinct layers. In reality, the boundaries between the two forms of law tend to blur and legal claims of authority are not territorial, but functional: it has even been argued that the EU already goes beyond the dichotomy between national and international law. ${ }^{32}$ After all, whereas in the classic federal model, the federal level normally possesses the authority to change the constitution, in the EU such authority is typically conferred upon the

The Law of Integration: Emergence of a New Phenomenon in International Relations, Based on the Experience of the European Communities (Sijthoff 1974) 30.

28 W. Wallace, 'Europe as a Confederation: the Community and the NationState' (1982) 21 Journal of Common Market Studies 57; K. Lenaerts, 'Constitutionalism and the Many Faces of Federalism' (1990) 38 American Journal of Comparative Law 206-33 (discussing 'integrative federalism'); K. Lenaerts, 'Federalism: Essential Concepts in Evolution - The Case of the European Union' (1997) 21 Fordham International Law Journal 746; A. von Bogdandy, 'The European Union as A Supranational Federation: A Conceptual Attempt in the Light of the Amsterdam Treaty' (2000) 6 Columbia Journal of European Law 27. For the area of criminal law, see C. Gomes-Jara Díez, European Federal Criminal Law - The Federal Dimension of European Criminal Law (Intersentia 2015).

29 A. von Bogdandy, 'The European Union as a human rights organisation? Human rights and the core of the European Union' (2000) 37 Common Market Law Review 1307; P. Eeckhout, 'The EU Charter of Fundamental Rights and the Federal Question' (2002) 39 Common Market Law Review 945.

30 S. Boom, 'The European Union After the Maastricht Decision: Will Germany be the "Virginia of Europe"?' (1995) 43 American Journal of Comparative Law 177.

31 Deviations from the classical model of the federal State have also been identified by J. Habermas, 'Democracy in Europe: Why the Development of the EU into a Transnational Democracy is Necessary and How It Is Possible' (2015) 21 European Law Journal 546, 555; J. Habermas, The Crisis of the European Union - A Response (Polity Press 2012) 24.

32 K. Tuori, European Constitutionalism (CUP 2015) 87. 
States. EU as transnational law thus consists not only of shared sovereignty and interacting executive, legislative and judicial powers, but also of complex networks, agencies, heterarchical sources of authority and soft legislation. ${ }^{33}$ True, the transnational dimension does not rule out, but instead, enhances the possibility of conflict between different sources of authority. Yet, the principle of primacy in EU law does not imply that, in case of conflict with national law, the latter is invalidated: the national rule is rather disapplied. In other words, conflicts concern the applicability, not the validity of norms. Following the federalist principle, instead, where conflicts over the orders' boundary emerge, the highest national court normally has ultimate authority to rule on such a boundary. ${ }^{34}$ Moreover, there is a second reason why federalist theories are flawed. Unlike the classic example of the US, the EU Member States already existed as independent entities before coming together. ${ }^{35}$ National polities possess a thick identity, which consists of social and cultural layers and a rich historical legacy weighing on their shoulders. While some federal traces can be identified in the process of integration, one should avoid attaching federalist labels to the EU institutional machinery too easily. ${ }^{36}$ Finally, there is a third reason why federalism does not appear as a viable solution for the EU experiment. The attempt of federalism to secure an authoritative foundation for the EU system-namely, to guarantee the security of the European liberal project-either by proposing a federal State or a federation of States as a finalité, leads to invoking a final source of legal authority (for example, through a Constitutional Treaty), which threatens the project itself by circumscribing its democratic

33 K. H. Ladeur, 'European Law as Transnational Law - Europe Has To Be Conceived As an Heterarchical Network and Not as a Superstate' (2009) 10 German Law Journal 1357; C. Calliess, 'Europe as Transnational Law - The Transnationalisation of Values by European Law' (2009) 10 German Law Journal 1367; R. Michaels, 'Does Brexit Spell the Death of Transnational Law?' (2016) 17 German Law Journal (Brexit Supplement) 51.

34 For example, according to Article VI, Cl. 2 of the US Constitution, the federal Constitution is 'the supreme law of the land' (so-called Supremacy Clause).

35 See e.g. A. Lincoln, 'Message to Congress in Special Session', 4 July 1861, in R. P. Basle (ed.) The Collected Works of Abraham Lincoln. Vol. IV (Rutgers University Press 1953) 433-35: 'The Union is older than any of the States; and, in fact, it created them as States'.

36 This does not mean, of course, that previously independent and selfgoverning parts may never come together, as the historical examples of the UK, Germany, Spain or Italy show. However, the process of federalisation should never be taken for granted and its complexity should be considered. 
credentials. The source of legitimacy for transnational integration seems to be identified ultimately through a top-bottom, rather than bottom-top, perspective. Local revindications, idiosyncrasies and impermeability are too often downplayed or ignored. This state of affairs has been confirmed time and again by the crises that have affected the European project, from Maastricht, to the failure of the Constitutional Treaty, to the economic and financial crisis, the refugee crisis and, finally, the Brexit crisis.

Having said that, since we should not tread on federal ground at full speed, how can we account for the creation of a self-nominated 'new legal order of international law', which confers rights upon individuals as part of the Member States' legal heritage ${ }^{37}$ What are the ultimate foundations - if any- of the EU as a polity? In what sense, and to what extent, should we ascribe to a 'compound or association of States' coming together formally by way of an international Treaty the "normative power' of a constitutional community? ${ }^{38}$ An answer to these dilemmas has been provided by the heterarchical paradigm.

The heterarchical features of the EU as transnational polity have been explored by different versions of constitutional pluralism from a variety of theoretical angles. Yet, most of these versions, while predicated upon normative frameworks of discursivity, constitutional tolerance and/or 'best fit', in one way or another, locate the ultimate source of authority at the EU level, thus translating to the new environment the traditional constitutional framework which is so familiar in State-centric approaches. In other words, although their initial assumption is the existence of multiple sites of legal authority and/or perspectives, they do not cut loose neatly and unambiguously from their moorings in the domestic configuration of a constitutional order. I will call these approaches, respectively, best-fit constitutionalism, messianic constitutionalism and contrapuntal constitutionalism. They either: (a) assume that the variously formulated claims may be balanced and reconciled by means of a set of competing principles (such as subsidiarity, legality, participation, accountability), ultimately conferring a higher presumptive weight to EU

37 Case 26/62 Van Gend en Loos EU:C:1963:1; Case 6/64 Costa v. ENEL EU:C:1964:66. The reference to 'international law' has later been abandoned but never explicitly denied.

38 I. Manners, 'Normative Power Europe: A Contradiction in Terms?' (2002) 40 Journal of Common Market Studies 235; K. Nicolaïdis, R. Howse, 'This is my EUtopia: Narrative as Power' (2002) 40 Journal of Common Market Studies 767; D. Edward, 'The Moral Case for Europe' University of Edinburgh Europa Working Paper 2013/6. The terms 'compound' and 'association' recall the German expressions 'Verbund' and 'Verband' respectively. 
claims $^{39}$ (best-fit constitutionalism); or (b) advocate a 'common-law type rationale', a telos and ethos which 'draws on and integrates the national constitutional orders' 40 (messianic constitutionalism); or (c) emphasize the importance of discursive practices taking place among not only the courts, but all the participants in the process of integration through 'contrapuntal principles'-yet, only to the extent that the emergence of conflicts of authority does not compromise the process itself (contrapuntal constitutionalism). ${ }^{41}$ These theories seek to achieve, promote or safeguard systemic coherence, but in so doing, they are bound to make use of the very language of the domestic constitutional framework they aim to overcome. In addition, the conclusions reached by these approaches are not far from the traditional and federalist accounts of EU integration, in one important aspect. They view the uniformity and efficiency of the EU legal system as a good in themselves, aiming at ensuring the existence of the common market. Ultimately, willingly or not, their arguments are formulated within the meta-rationale of security, as existential requirement of the EU legal order. However, they do not delve more deeply into the nature of this existential requirement, despite recognising that Europe has a 'constitution but without constitutionalism', ${ }^{42}$ or 'a constitutional body without a soul'. ${ }^{43}$

The preceding observations thus confirm that systemic plurality and the need for mutual accommodation are questions that should not be underestimated. As they test the legitimacy of the authority claim of the EU as a polity and legal order, they touch upon its very foundations.

39 M. Kumm, 'The Jurisprudence of Constitutional Conflict: Constitutional Supremacy in Europe before and after the Constitutional Treaty' (2005) 11 European Law Journal 262, 302.

40 J. Weiler, 'European Neo-constitutionalism: in Search of Foundations for the European Constitutional Order' (1996) 46 Political Studies 517, 532. Weiler goes as far as proposing a 'Constitutional Council for the Community', with jurisdiction over issues of competences, following the French model. Later, he turns towards a more heterarchical view in J. Weiler, 'On the power of the Word: Europe's Constitutional Iconography' (2005) 3 ICON 173. See also J. Weiler, 'In Defence of the Status Quo: Europe's Constitutional Sonderweg' in J. Weiler, M. Wind (eds.) European Constitutionalism Beyond the State (CUP 2003) 23.

${ }^{41}$ M. P. Maduro, 'Contrapunctual Law: Europe's Constitutional Pluralism in Action' in N. Walker (ed.) Sovereignty in Transition (Hart 2003) 501, 523-24.

42 J. Weiler, The Constitution of Europe (CUP 1999) 298.

43 M. P. Maduro, 'Europe and the Constitution: What if This is as Good as It Gets?' in J. Weiler, M. Wind (eds.) European Constitutionalism Beyond the State (CUP 2003) 77. 
The difficulty of translating the language of constitutionalism to a new environment is more convincingly addressed by other theories, which take the problem of heterarchy more seriously and can be labelled as epistemic or sometimes even radical constitutional pluralism. ${ }^{44}$ These theories still work within the mind-frame of constitutional pluralism: they view European integration as emblematic of the possibility of having multiple legal orders exercising epistemic claims towards ultimate legal authority within the same political space. ${ }^{45}$ However, they also recognize that there is no final reference point which can usefully offer a mechanism to reconcile the various claims. Their vision is simultaneously descriptive and normative, as they assert that it would be possible for mutual learning and cross-fertilisation to take place at a metaconstitutional level, as a form of reflexivity. ${ }^{46}$ Contrary to classic or neo-classic versions of constitutionalism (which, while discussing multilevel heterarchical arrangements above or beyond the State, still cling to value homogeneity, coherence of the whole and single sovereignty as guarantees of a process of constitutional integration), ${ }^{47}$ epistemic or radical pluralism admits that 'law becomes particular - the reflection of particular values and particular projects of individuals and groups, in competition with the values and projects of others' ${ }^{48}$ Yet, while epistemic pluralism still admits of the possibility of 'various contending global meta-principles of legal authority', or 'orders of order', ${ }^{49}$ radical pluralism promotes mutual accommodation in a contested post- or transnational political space simply by bracketing the confrontation of

44 As is well known, the first proponent of the idea of constitutional pluralism, MacCormick, moved from an initially radical stance to a position that he himself named 'pluralism under international law', whereby international law operates according to Kelsenian criteria, as 'common ground of validity' both of domestic and EU law. See N. MacCormick, 'Beyond the Sovereign State' (1993) 56 Modern Law Review 1; N. MacCormick, 'Risking Constitutional Collision in Europe?' (1998) 18 Oxford Journal of Legal Studies 517.

45 N. Walker, 'The Idea of Constitutional Pluralism' (2002) 65 Modern Law Review 317.

46 Ibid. 334.

47 I. Pernice, 'Multi-level Constitutionalism in the European Union' (2002) 27 European Law Review 511.

48 N. Krisch, Beyond Constitutionalism - The Pluralist Structure of Postnational Law (OUP 2010) 306.

49 N. Walker, 'Beyond boundary disputes and basic grids: Mapping the global disorder of normative orders' (2008) 6 International Journal of Constitutional Law 373, 386. 
entrenched systems of values or principles. ${ }^{50}$ From a different, yet analogous perspective, the plurality of legal authorities and sites of decision-making has been reinterpreted by some recent works, which dismiss the vocabulary of coherence, universality and sovereignty and opt for an efficiency-based configuration of multi-level governance, in which emphasis is placed on direct deliberation at the local level, beyond the reach of courts. ${ }^{51}$

The most significant contribution of this last group of theories is that, while departing from different premises, they look more deeply at the novel character of European integration, with a level of perspicacity that is missing in the other approaches. Yet, just like these other approaches, one important consideration has been left aside or addressed only marginally: the question of security as a meta-rationale of the European project. This question has become more pressing in the face of the recent crises of the EU.

As will be discussed in the next sections, analyzing the deep causes and effects of the crisis inevitably leads to a problematisation of the 'people' as constituent power and the related 'return of the political'. When looking at the unfolding of security as a meta-rationale, three important considerations should be borne in mind.

First, through the lens of security, the implications of heterarchy must be recognized and explored fully. In particular, the claim that 'the federation contract aims to establish a permanent contract, not just a provisional regulation', ${ }^{52}$ and 'the federation aims at the preservation of the political existence of all members in the framework of the federation' 53 may apply to the heterarchical paradigm as well. As a result, the question of sovereignty as a 'decision on an existential conflict' is always possible and always remains open. ${ }^{54}$

50 N. Krisch, 'Who is Afraid of Radical Pluralism? Legal Order and Political Stability in the Postnational Space' (2011) 24 Ratio Juris 386.

51 O. Gerstenberg, C. Sabel, 'Directly-Deliberative Polyarchy: An Institutional Ideal for Europe?' in C. Joerges, R. Dehousse (eds.) Good Governance in Europe's Integrated Market (OUP 2002).

52 C. Schmitt, Constitutional Theory (Duke University Press 2008) 385.

53 Ibid. 386.

54 Ibid. 389-90. Interestingly, Habermas also argues that in supranational political communities, unlike in federal states, the issue of ultimate decisionmaking authority must not be resolved through hierarchization': J. Habermas, 'Citizen and State Equality in a Supranational Political Community: Degressive Proportionality and the Pouvoir Constituant Mixte' (2017) 55 Journal of Common Market Studies 171, 174. However, he adds that leaving the question open 
Second, a constitutional polity that seeks to preserve its substantive framework from internal and external threats may take measures violating the formal constitution or going beyond its letter.

Such measures may either promote security stricto sensu at the expense of fundamental rights, or strengthen fundamental rights, for example through an expansive interpretation of provisions on fundamental rights. The discourses of security stricto sensu and fundamental rights flow from the meta-rationale of security and at the same time shape European subjectivity and collective self-representation. As a result of their constant interaction, the EU faces a tension between its normative and its imperialistic dimension. ${ }^{55}$

Finally, the way the discourses of fundamental rights and security stricto sensu develop is revelatory of the inner nature of constituent power in the EU.

Before addressing these issues more deeply, it may be worthwhile to consider some of the most relevant criticism that has been levelled at the general approach of constitutional pluralists and the heterarchical paradigm. Critical arguments may be divided into two general categories: the 'political morality or federalist objection' and the 'political authority objection'. These general objections represent enriched versions of the broad approaches examined earlier, namely the 'federalist' approach and the 'State-centric approach'.

The 'political morality or federalist objection' draws on two lines of thought: the Madisonian and the Dworkinian. Its main claim is that any analysis of European integration should not be approached through the prism of conflict, but through the normative archetype of unity. Both lines of thought insist on such archetype, while at the same time abhorring the 'tyranny of the majority', although the former perhaps has a more pronounced Calvinist inspiration, driven by the intent to remedy man's selfish instincts. ${ }^{56}$ Thus, the Madisonian line argues that, as the EU is a 'federation of States' or is rapidly becoming one, constitutional pluralist claims are either nothing but disguised federalist claims, ${ }^{57}$ or

should not be allowed 'at the expense of a principle of democracy that has only been realized in the nation-state'.

55 M. Fichera, 'Carl Schmitt and the New World Order: A View from Europe' in P. Minkkinen, M. Arvidsson, L. Brannström (eds.) The contemporary relevance of Carl Schmitt - Law, Politics, Theology (2015 Routledge) 165.

56 G. W. Sheldon, The Political Philosophy of James Madison (John Hopkins University Press 2001).

57 R. Schütze, 'Constitutionalism and the European Union' in C. Barnard, S. Peers (eds.) European Union Law (OUP 2014) 71; R. Schütze, 'Federalism as 
dangerous assumptions that may threaten the survival of the Eurozone, if not the entire EU legal order. ${ }^{58}$ There is nothing special about the political and constitutional dualism of the EU's structure and its divided and pooled sovereignty is a political and historical phenomenon whose features are not unique. Thus, the principle of supremacy of EU law should be given its real meaning, which is, inevitably, that EU law must prevail, as it is the only way to ensure uniform compliance by Member States. ${ }^{59}$ The Dworkinian line, instead, assumes that the idea of law, no matter how conceived, always refers to an objective value of political morality (e.g. justice or equality), which means that the content of legal rights and duties often does not correspond to the content of a rule enacted or practiced by a particular institution. In other words, cases of radical conflict are absent, as what really matters is not the-alleged or real-supremacy of EU law, but the moral and political significance of a common project for the realization of the internal market. As a result, through this conception of 'harmonic law', (a) conflicting national constitutional provisions are simply irrelevant, (b) the question of the ultimate authority to determine the competence the EU (the so-called kompetenz-kompetenz) is objectively solved by political morality and (c) inviolable fundamental rights are put beyond the reach of the political process of collective decision. ${ }^{60}$

The 'political authority objection' comes in different guises, mostly pointing to the contradiction of combining constitutionalist and pluralist claims. One of these guises is that of constitutional skepticism. Thus, it has been argued by Christodoulidis that, of the three dimensions within which contemporary constitutionalism struggles-the spatial, the temporal and the normative - at least the second and the third present

Constitutional Pluralism: Letter from America' in M. Avbelj, J. Komarek (eds.) Constitutional Pluralism in the European Union and Beyond (Hart 2012) 185.

58 R. D. Kelemen, 'On the Unsustainability of Constitutional Pluralism European Supremacy and the survival of the Eurozone' (2016) 23 Maastricht Journal of European and Comparative Law 136, 144.

59 F. Fabbrini, 'After the OMT case: The Supremacy of EU Law as the Guarantee of the Equality of the Member States' (2015) 16 German Law Journal 1003, 1016.

60 G. Letzas, 'Harmonic Law - The Case Against Pluralism' in J. Dickson, P. Eleftheriadis (eds.) Philosophical Foundations of European Union Law (OUP 2012) 77, 94-102. 
\}unsurmountable hurdles. ${ }^{61}$ From the temporal perspective, Christodoulidis observes, the dilemma of the foundation of a polity has never been solved once and for all, for, whether this origin is interpreted as a repository of discursive/rational principles (universalism), or of popular conscience (particularism), 'the suspension of the foundation over and above political time, the dictate to return and to repeat, overwhelms the possibilities of becoming' ${ }^{62}$ From the normative perspective, the reflexive conception of democracy that is promoted by constitutional pluralism's call for inclusive normative coherence is judged unfeasible, as every concession to pluralist claims implies a withdrawal of the institutional element. ${ }^{63}$ Those who are inspired by practical philosophy often seek to approach questions of politics not so much in terms of justice, but in terms of freedom, with the aim of precluding practices of governance from becoming 'closed structures of domination under settled forms of justice'.64 This is precisely what is contested by constitutional skepticism. In other words, attempts to 'square the circle' between irreconcilable claims generate impossible demands on constitutionalism. True, concedes Christodoulidis, constitutionalism provides a foundation for democracy, as 'a matrix that secures continuity against rupture and thus guarantees the unity of the system over time' ${ }^{65}$ Yet, for him, the higher the level of inclusiveness that constitutionalism is prepared to admit, the higher the level of indeterminacy it must accept within itself, which can only be allowed to a certain extent. Thus, constitutionalism, as 'a temporarily open-i.e. ceaselessly-renegotiated disorder', is inevitably 'the name of the control that secondary rules of change exert on "transgression". Not only is the Will-the moment of decision-circumscribed within the norm, but the norm itself is subject to an entrenchment and a strict control of the possibilities of its changing'. ${ }^{66}$ What does this mean? Are we facing the ultimate paradox, the paradox of all paradoxes? The author is ready to go all the way down and highlight, in his words, the 'aporetic' structure at the heart of the very principle of popular sovereignty, as he concludes

61 E. Christodoulidis, 'Constitutional Irresolution: Law and the Framing of Civil Society' (2003) 9 European Law Journal 401, 406 (in response to Walker's approach).

62 Ibid. 407.

63 Ibid. 408.

64 J. Tully, Public philosophy in a new key Vol. I: Democracy and Civic Freedom (CUP 2009) 38.

65 E. Christodoulidis, 'Constitutional Irresolution' supra 419.

66 Ibid. 419. 
that 'a people cannot announce itself as a people unless it is constituted as such first, in which case the announcement is no longer a performative act of self-definition'. ${ }^{67}$ Although, a posteriori, a polity's acts of announcement and self-definition can be rationalized retrospectively as possessing a constitutional authorship, they cannot be interpreted as constitutional acts at the time of their doing, but only as political acts. This is the final blow that is struck by Christodoulidis against the ambitions of inclusive constitutionalism.

Similarly, Loughlin, too, maintains that constitutional pluralism is an oxymoron, as it assumes erroneously that 'a pluralism of values and institutions can also be extended to a pluralism of foundations'.68 According to Loughlin, constitutional pluralists do not offer a plausible answer to the question of political authority (or sovereignty). Just like MacCormick's mistake is that of positing the equivalence in status and authority of all normative orders and constitutions - thus moving uneasily between a merely descriptive, sociological analysis and the normative stance of 'pluralism under international law' - so Walker's flaw is that of wavering between an account of the current state of affairs and a call for an increased authority of the EU through the process of constitutionalisation. ${ }^{69}$ The fundamental assertions of constitutional pluralismlocating the foundation of political authority in the constitution, depicting political authority as heterarchical, rather than hierarchical, and either leaving the question of ultimate authority open, or reformulating it within the framework of general principles-are, for Loughlin, unacceptable. ${ }^{70}$ In other words, a self-proclaimed constitution cannot claim political authority without relying on the State-its apparatus, its values, its legitimacy. This is why, in Loughlin's view, any argument in favor of the so-called 'European constitutionalism', in the sense that participation and representation should not be limited by the requirement of belongingness to a national polity (i.e. national citizenship), is a 'direct attack on the inclusionary-exclusionary dynamic that lies at the core of any political understanding. It is a direct attack on the concept of the political' ${ }^{71}$ On a

\footnotetext{
67 Ibid. 425.

68 M. Loughlin, 'Constitutional Pluralism: An Oxymoron?' (2014) 3 Global Constitutionalism 9, 29.

69 Ibid. 16-21.

70 Ibid. 22-24.

71 Ibid. 28. For the argument from 'European constitutionalism', see M. P. Maduro, 'Three Claims of Constitutional Pluralism' in M. Avbelj, J. Komarek (eds.) Constitutional Pluralism in the European Union and Beyond (Hart 2012)
} 67. 
similar, although less State-centric wavelength, it is argued that 'political constitutionalism depicts the polity dimension of the constitution. Reducible neither to positive law nor to legal-moral principle, this resonates with the ancient signification of constitution as metaphor for the health and strength of the body politic', so that 'the polity is instead identified as a fragmented, contested and heterogeneous plurality'. ${ }^{72}$ This means that, just like what is labelled 'foundational constitutionalism' reifies the constituent subject, by configuring 'the people' or 'the State' as a prior existential unity, so the so-called 'freestanding constitutionalism' (a broad category including constitutional pluralism, too), being 'centered on the fiction of the individual rights-bearer', is not able to recognise the political and polity-building dimension of constitutional principles, rights or values, i.e. 'the priority of politics over morality'. ${ }^{73}$

To a careful reader, challenges to constitutional pluralism and alternative versions of the relationship between EU law and national law turn out to focus on 'the deeper structural condition of the EU as a divided power system', ${ }^{74}$ and therefore-we would add—on the conditions, the criteria, or the paradigms through which it can best be defined and preserved. In other words, their claims can be reformulated as security claims. From this perspective, systemic plurality is the best paradigm - at least in the descriptive sense. Why is it so?

As noted earlier, systemic plurality is a condition that escapes traditional constitutional conceptions. One reason for this peculiarity is that political morality does not stand as an overarching value, but is subject to a multitude of claims of authority, which are equally defensible and inevitably conflicting. To believe otherwise leads either to a fictitious world, one in which processes of institutionalization and sedimentation may take place regardless of their social and cultural embeddedness, or to structural rigidity, thus impeding any form of institutional diversity in the name of an allegedly superior ideal of government. Any federalist approach, no matter how finely elaborated, must come to terms with the factual lack of political support for such a prospect, as well as the risk of reproducing, once again, Statist premises and logic. ${ }^{75}$ Yet, if this is true, how to address the problem of recognizing and coming to terms with the political and polity-building dimension of constitutional principles, rights

72 M. Wilkinson, 'Political Constitutionalism and the European Union' (2013) 76 Modern Law Review 191, 207.

73 Ibid. 209-10.

74 N. Walker, 'Constitutional Pluralism Revisited' (2016) 22 European Law Journal 333, 337.

75 Ibid. 346. 
or values? ${ }^{76}$ How to account for the genuine concerns raised by the 'political authority objection', which generates serious doubts as to whether it is really possible to reconcile the constitutionalist and pluralist claims? One answer could be that of envisaging 'a clearer and more coherent framework of governance', without 'placing too many matters beyond the reach of ongoing political engagement and contestation' ${ }^{77}$ This consideration calls for an effort to uphold a large scale political process of renewal, in which the reasons of the living together of multiple constituencies are re-examined. The emergence of repeated crises ought to be seen as an opportunity to reframe such process within the meta-rationale of the security of the European liberal project. ${ }^{78}$

Any such analysis will, no doubt, need to rescue the elements of truth that can be found in the theories on the process of European integration that have been elaborated since its onset. For this purpose, some of the most penetrating works draw on two general attitudes: critical optimism and genuine pessimism. From a critically optimistic perspective, old and new constructivism may still provide interesting hints as to why a large part of the process of European integration is placed beyond the reach of political contestation: transnational agencies and stakeholders, formal and informal procedures and practices form part of a functional framework of shared interests which, through multiple interactions between social actors, are key elements of EU polity-building. ${ }^{79}$ A more disenchanted, genuine pessimism may usefully expose what appears as the purely economic, functionalist nature of the EU juggernaut. ${ }^{80}$ Yet, neither

76 M. Wilkinson, 'Political Constitutionalism and the European Union' supra 191.

77 N. Walker, 'Constitutional Pluralism Revisited' supra 353. See also D. Grimm, 'The Democratic Costs of Constitutionalisation: The European Case' (2015) 21 European Law Journal 460.

78 M. Fichera, 'Europe's Double Face: The Financial and Constitutional Crisis is a Matter of Security' - Eutopia Magazine - Ideas for Europe, 18.05.2015, at http://www.eutopiamagazinearchive.eu/en/massimo-fichera/speakers-corner/ europes-double-face.html.

79 E. Haas, 'Does Constructivism Subsume Neo-functionalism?' in T. Christiansen, K. E. Jorgensen, A. Wiener (eds.) The Social Construction of Europe (Sage 2001) 21, 27-29; J. Checkel, 'Social Construction and European Integration', in T. Christiansen, K. E. Jorgensen, A. Wiener (eds.) supra 50; J. Shaw, A. Wiener, 'The Paradox of the European Polity' in M. G. Cowles, M. Smith (eds.) The State of the European Union Vol. 5: Risks, Reform, Resistance, and Revival (OUP 2000) 64.

80 T. Isiksel, Europe's Functional Constitution - A Theory of Constitutionalism Beyond the State (OUP 2016). 
constructivism nor recent theories of functional differentiation or functional constitutionalism take seriously into account the return of the political, and the dimension of conflict that is associated with it. They may critically examine transformative processes of integration, particularly as regards the relationship between the EU and the national level, ${ }^{81}$ or point to the self-referential character of the EU polity-victim of its own instrumental rationality, and thus unable to express or resuscitate its ultimate normative foundations. ${ }^{82}$ They may, alternatively, lay bare the functional nature of EU constitutionalism, as ambitions of deeper integration are thwarted by the 'force of economic necessity', confirmed by the recent economic and financial crisis. ${ }^{83}$ Nevertheless, neither critical optimism nor genuine pessimism quite capture the multidimensional challenge of liberal democracy: exporting its ideal of the rule of law, its promise of prosperity and its aspirations of universality to the transnational sphere.

To be sure, genuine pessimism, on the rare occasions it has been declared, has convincingly emphasized the degenerating shift in European integration from classic market liberalism to 'market holism', which implies an ever more penetrating encroachment upon nationally reserved areas, such as health, social policy and education, in the name of market integration and uniformity. ${ }^{84}$ Under this Tocquevillian scheme, the delegation of the responsibility to decide on collective issues to administrative and executive authorities is simply the outcome of a form of individualism, which encourages the pursuit of self-interest and the lack of engagement in the public sphere. ${ }^{85}$ On such a view, the EU, which is heavily affected by this form of individualism, is characterized by a 'normativity of approximation', which, unlike the State's 'normativity of self-government', merely promotes cross-border economic transactions and market convergence between separate polities, so that the formula of mixed constitution, rather than any evocation of a single people, befits it more appropriately. ${ }^{86}$

Despite the undeniable value of these last contributions, some aspects of this general inquiry are still left in the shadows. First, they take the

81 T. Christiansen, K. E. Jorgensen, A. Wiener (eds.) supra 11.

82 J. Priban, 'The Self-Referential European Polity, its Legal Context and Systemic Differentiation: Theoretical Reflections on the Emergence of the EU's Political and Legal Autopoiesis' (2009) 15 European Law Journal 442.

83 T. Isiksel, Europe's Functional Constitution supra 230.

84 A. Somek, Individualism (OUP 2008).

85 Ibid.

86 Ibid. 241-44. 
vocabulary of liberal constitutionalism too easily for granted. Second, both the heterarchical paradigm and its critics have failed to delve more deeply into the European liberal project's claim of neutrality, i.e. its alleged lack of political engagement. These issues will be considered later in this work.

For the moment, we may thus remark that the main arguments developed in the next chapters are that:

a) The crisis of the European liberal project is a reflection of the crisis of liberal constitutionalism itself and its reasons ought to be examined more carefully;

b) The claim of neutrality of the European liberal project hides a clear political programme, which has been camouflaged behind the framework of technocratic governance provided by the Treaties;

c) Security as a meta-rationale can be employed as a scheme of interpretation not only of the process of EU integration, but also of all attempts made by scholars in describing and/or justifying this process.

In other words, a first underlying theme, in the debate on the process of constitutionalisation of the EU, ought to be not so much what the nature of the EU is, but the meta-rationale of the process of EU integration. Why have we been witnessing increasing EU integration? This question has surprisingly been ignored or sidelined in practice, despite its fundamental importance, especially as, crisis after crisis, EU constitutionalism seems to be at a loss and in retreat. This is puzzling, because in fact, on a closer look, all theories of EU integration are inadvertently informed by the security meta-rationale. If the above is true, a second underlying theme must then be why the security meta-rationale represents the substrate of our inquiry into the process of European integration-and, related to this question, whether or not this more or less implicit meta-rationale is useful or somehow constrains our vision of the European project.

\section{THE SECURITY OF THE EUROPEAN PROJECT}

Never as in recent times has the European liberal project shown its true multi-faceted, contradictory foundation, i.e. the fact that it is premised on security as a meta-value, or meta-rationale that supports and justifies its existence. In a way, the recent Brexit crisis, which is ongoing at the time of writing, sums up all previous crises and raises the stakes even higher 
than previously thought. As repeatedly mentioned, this chapter suggests that one way of looking at the crisis is through the lens of security. It argues that security lies at the heart of Europe's constitutional identity. The reason for this is not only that the Treaties of Rome were signed and ratified with the idea of creating a safe zone in which war would be banned among the countries participating in it. Security in the broad sense is also a fundamental rationale upon which the European liberal project is founded. In fact, security's essential features are existential. In other words, security measures are always justified by a sense of urgency and, in extreme circumstances, by the need to face threats to the survival of a community. The importance of Europe is expressed not merely by the need to develop shared values and establish procedures to enforce them (or, as some would say, 'integration through law'), but also by the urge to ensure that these values are protected over an extended period of time. Yet, at the same time security as meta-value also inevitably embraces and challenges all other values. How does this happen? Does not this amount to arguing that security is a self-defeating meta-rationale?

As noted earlier, prior to debating whether Europe is a polity in fieri, an international organisation, a quasi-federal State or something else, we should reflect on the reasons why Europe exists. Why Europe, rather than something else? The suggestion in this work is that we should look more carefully at the image of 'Europe as an area of freedom, security and justice (AFSJ)' that is being increasingly projected by the EU. The implication is that the AFSJ plays a relevant role not so much as a policy area, but as an overarching aspiration of the EU as a whole. It is by examining the self-representation of the EU as a polity, which develops in the direction of an AFSJ, that we may reveal something new, or unexplored, about the European liberal project.

The EU is normally configured as an internal market with an essentially economic core. ${ }^{87}$ From this perspective, the traditional narrative depicts the liberal project of European integration as the gradual and progressive development from an economic community, in which fundamental rights are absent, to a fully fledged organization or polity, which is 'founded on the values of respect for human dignity, freedom, democracy, equality, the rule of law and respect for human rights ...'s8

87 See e.g., in different fields, K. Armstrong, S. Bulmer (eds.) The governance of the Single European Market (Manchester University Press 1998); C. Damro, 'Market Power Europe' (2012) 19 Journal of European Public Policy 682.

88 Article 2 Treaty on the European Union (TEU), OJ C 326 26.10.2015. 
According to this narrative, the European Community/EU, whose original spirit is that of preventing the return of war among European countries, would have finally emerged as an 'enlightened' human rights regime, thanks to the initiative of a few outstanding political leaders and the relentless activity of the Court of Justice of the European Union (ECJ). ${ }^{89}$ In a way, the bias of legal determinism, which consists in believing that the European liberal project expresses a pre-determined finalité which must be achieved through a more or less gradually competence-accruing development, lurks behind much of EU legal studies. The culmination of the EU development would indeed be the achievement of an AFSJ, which is, in the words of the Treaty of Lisbon, 'offered' by the EU to its citizens. 90

This book aims to question this received narrative and argue instead that, right at the core of the EU, security and fundamental rights operate as self-justifying discourses of power, and therefore in terms of empowerment both of the EU citizen and of the EU as a collective entity. ${ }^{91}$ Power is here interpreted as impersonal, diffuse, anonymous and allinclusive. ${ }^{92}$ As will be explained in the next sections, these discourses are constitutive of the EU project at a deep, foundational level. Yet, there are relevant contradictions in the interaction between these discourses, because the EU citizen cannot be empowered without at the same time being disempowered. Europe as an AFSJ constitutes and justifies itself as a polity through a multidimensional vision of security, which merges with fundamental rights.

89 P. Pescatore, 'The Context and Significance of Fundamental Rights in the Law of the European Communities' (1981) 2 Human Rights Law Journal 295; K. Lenaerts, E. de Smijter (eds.) 'A "Bill of Rights" for the European Union' (2001) 38 Common Market Law Review 273; F. G. Jacobs, 'Human Rights in the European Union: The Role of the Court of Justice' (2001) 26 European Law Review 331; S. Besson, 'The European Union and Human Rights: Towards a Post-national Human Rights Institution' (2006) 6 Human Rights Law Review 323.

Article 3 TEU, above.

91 M. Dougan, N. Nic Shuibhne, E. Spaventa (eds.) Empowerment and Disempowerment of the European Citizen (Hart 2012). 'Narrative' is considered here as an identity-driven and identity-reproducing process, whereby events are presented and linked in a causal connection to provide an interpretative scheme of reality and sometimes modify it. See e.g. R. R. Krebs, Narrative and the Making of US National Security (CUP 2015). For 'discourse', see further below in this chapter.

92 M. Foucault, Power, Truth, Strategy (Feral Publications 1979). 
Contrary to what most scholars believe, there exists some continuity in the unfolding of security and fundamental rights discourses, based on the dichotomy inclusion/exclusion, and running from the origins of Europe as the European Economic Community. ${ }^{93}$ For example, EU citizenship is elaborated on the basis of broad notions, in such a way that inevitably rules out in one way or another specific categories of individuals, such as third country nationals in some circumstances, Roma citizens, family members etc.

As already mentioned, the security meta-rationale was present from the beginning, at a foundational stage, and was conceived as the "bracketing of war', i.e. the creation of a peaceful free trade area. On the one hand, the human rights discourse already emerged in the drafting documents of the early 1950s (for example, those relating to the European Political Community). ${ }^{94}$ Human rights tend to extend to a variety of fields, and may sometimes conflict with other fields of EU law, such as free movement rights. ${ }^{95}$ On the other hand, the security discourse is also expansive: it no longer appears in narrow, traditional terms, but embraces other fields, such as the environmental or the economic field.

The history of Europe as a polity is marked by the discourses mentioned above much more than may appear at first sight, as they appear formally as universalistic discourses, but in fact operate along an ambiguous, nuanced inside/outside dichotomy. ${ }^{96}$ In reality, what ultimately emerges is the imperialistic dimension of security and fundamental rights. ${ }^{97}$ The EU liberal project of integration employs them to justify its own existence and deny conflict. The reality is that conflict cannot be denied and, on the contrary, it is constitutive of the relationship both between the EU and its Member States and between the EU and the rest of the world. For example, it was the need to reaffirm the supremacy of

93 In terms of inclusion/exclusion, see G. Teubner, Constitutional Fragments: Societal Constitutionalism and Globalization (OUP 2012) 133.

94 G. de Búrca, 'The Road Not Taken: The European Union as a Global Human Rights Actor' (2011) 105 American Journal of International Law 649.

95 See e.g. Case C-438/05 International Transport Workers' Federation and Finnish Seamen's Union v Viking Line; Case C-341/05 Laval v Svenska Byggnadsarbetareförbundet.

96 See e.g. M. B. Dembour. 'Human Rights talk and anthropological ambivalence: the particular context of universal claims' in O. Harris (ed.), Inside and Outside the Law - Anthropological studies of authority and ambiguity (Routledge 1996).

97 As explained in M. Fichera, 'Security issues as existential threats to the community' in M. Fichera, J. Kremer, (eds.) Law and security in Europe Reconsidering the Security Constitution (Intersentia 2013) 85. 
Community law that led the ECJ to increasingly carve out a role for human rights in its case law. ${ }^{98}$

The image of 'Europe as an AFSJ' is often criticized by doctrinal law scholars. In the eyes of many detractors, the creation and progress of AFSJ law may look like little more than window-dressing. They would perhaps insist that the AFSJ plays at most a marginal role in the architecture of European integration, and their conviction that the economic dimension has always been prominent might seem strengthened by the fact that exceptional measures to handle the financial crisis of the Eurozone have been in the limelight recently. While much of the criticism that is levelled at the AFSJ as such (for example, as regards the imbalance towards measures of proceduralisation) ${ }^{99}$ is understandable, those critics that tend to belittle the significance of the AFSJ are not correct. In fact, AFSJ represents the most important recent stage of development in European constitutionalism. Its relevance lies beyond its mere incorporation in the so-called Community pillars and goes to the heart of EU reflexivity, because it helps us to understand better the nature of the EU process of polity-building. ${ }^{100}$ Over the years a powerful and pervasive security discourse has been unfolded, with an increasing focus on two functions, i.e. both securing the functioning or smooth operation of the internal market and ensuring a secure marketplace. On the one hand, the internal market needs to be socially embedded in order to acquire a properly European character. On the other hand, the EU project needs to be preserved at all costs in the face of new forms of crisis-and

98 Starting from Case 29/69 Stauder v. City of Ulm 1969 ECR 419; Case 11/70 Internationale Handelsgesellschaft v. Einfuhr- und Vorratstelle für Getreide und Futtermittel 1970 ECR 1125; Case 4/73 Nold v. Commission 1974 ECR 491.

99 By 'measures of proceduralisation' here I mean measures that emphasise effectiveness at the expense of fundamental rights. See e.g. S. Peers, 'Salvation Outside the Church: Judicial Protection in the Third Pillar After the Pupino and Segi judgements' (2007) 44 Common Market Law Review 883. On the compatibility between automaticity and fundamental rights, see V. Mitsilegas, 'The Limits of Mutual Trust in Europe's Area of Freedom, Security and Justice: From Automatic Inter-State Cooperation to the Slow Emergence of the Individual' (2012) 31 Yearbook of European Law 319.

100 Reflexivity has been a constant feature of the EC/EU. As Preu $\beta$ observed, 'from its very beginning the Community possessed institutions which allowed it self-observation and self-evolution'. See U. K. Preuß, 'Citizenship in the European Union: A Paradigm for Transnational Democracy?' in D. Archibugi. D. Held, M. Köhler, Re-imagining Political Community - Studies in Cosmopolitan Democracy (Polity Press 1998) 138. 
new forms of crisis emerge because of new forms of insecurity and threat, from ecological to financial, to, ultimately, a crisis of intelligibility. ${ }^{101}$ In the face of multiple crises, AFSJ acquires a distinctive meaning, because security functions as the pre-condition for the existence of the internal market. The double supporting function of AFSJ mentioned above is even more evident in the newly adopted EU Justice Agenda. ${ }^{102}$ Moreover, AFSJ can be identified as a space by means both of a territorial claim and a fabrication of symbols. ${ }^{103}$

AFSJ as a space is in reality a claim to universality, beneath which lie remarkable contradictions that affect the heart of the European liberal project, i.e. a project based on the liberalisation of a peaceful market and the internal and external projection of its values as universal. In the radicalised version of this project, market values have almost absolute priority and may trump conflicting values. ${ }^{104}$ AFSJ consists, in other words, in a simultaneous reinterpretation of Europe not merely as a legal and political, but mainly as a moral space, which, through the security discourse, tends to expand both internally and externally. All keystones of EU integration, including citizenship, the four freedoms, the notion of uniform and effective implementation of EU law, and so on, are exposed to the expansion of the security discourse. Read through these lenses, AFSJ thus acquires both an existential and an imperialistic dimension that have not been analysed sufficiently yet.

The Treaty of Lisbon has brought the process of EU polity-building further by abolishing the distinction between pillars and, at the same time, keeping a balance between the supranational interests and the safeguards of national competences. All fields of what was formerly known as justice and home affairs, namely immigration and asylum, judicial cooperation in civil, commercial and criminal matters, and family law, have been reunited and explicitly connected with the free movement of persons and EU citizenship. ${ }^{105}$ As a result of the Lisbon Treaty

101 J. Clam, 'What is A Crisis?' in P. Kjaer, G. Teubner, A. Febbrajo (eds.) The Financial Crisis in Constitutional Perspective - The Dark Side of Functional Differentiation (Hart 2011) 189.

102 Communication from the Commission - The EU Justice Agenda for 2020

- Strengthening Trust, Mobility and Growth within the Union 11.3.2014 COM (2014) 144 final

103 See e.g. European Council Conclusions, Brussels, 27 June 2014 EUCO $79 / 14$

104 A. Somek, Individualism supra.

105 See e.g. eur-lex.europa.eu. 
innovations, for example, the Charter of Fundamental Rights has been made legally binding and the powers of the European Parliament have been strengthened. AFSJ should therefore be seen also as a way of dealing with Europe's complexity and multi-level realities. AFSJ, in this sense, pursues an objective of coherence and uniformity of application, and thus a model that goes beyond mere inter-State cooperation. However, it is a fact that many Member States have failed to implement EU legislation in AFSJ matters, or have implemented them in inhomogeneous ways. ${ }^{106}$

As noted earlier, 'Europe as AFSJ' is considered here not as a particular branch of EU law, but symbolically, as an aspiration that cuts across several areas of EU law. There is, in this sense, an evolutionary line to be drawn from the beginning to the current situation and 'Europe as AFSJ' seems to be the final claim of the European project, one that is put forward as a security claim. Yet, it needs to be pointed out that the argument developed in this book is neither purely legal, nor purely political-but crosses both fields, because the EU is considered simultaneously as a legal system/order and as a polity.

From this angle, we may thus distinguish six dimensions in our inquiry on the security of the European project. Each dimension relies upon a conceptual dichotomy through which it is possible to operationalize it. The first dimension is the spatial dimension: space is a category that explains the development of the EU as a geo-political and geo-legal entity, related to other geo-political and geo-legal entities (not only in relation to enlargement policies, the Common Foreign and Security Policy and in general external relations, but also, for example, trade and environment). This dimension is operationalized through the dichotomy inside/outside. The questions that ought to be asked in this respect are therefore: who is the Other? Where is it located? As our analysis of the free movement provisions and citizenship provisions will show, there exist in reality multiple inside and outside even within the EU polity and this reveals challenges and contradictions that are not always reconcilable. The confrontation with the Other may thus turn into a potential

106 V. Mitsilegas, 'The Area of Freedom, Security and Justice from Amsterdam to Lisbon. Challenges of Implementation, Constitutionality and Fundamental Rights', General Report, in Julia Laffranque (ed.), The Area of Freedom, Security and Justice, Including Information Society Issues. Reports of the XXV FIDE Congress, Tallinn 2012, Tartu University Press, Vol. 3, 21; S. Peers, EU Justice and Home Affairs Law (OUP 2011 3rd edn). 
threat to the European project. The second dimension is a temporal one: time is a factor that affects legislative and policy measures, as well as a concept that we utilize to explain or examine the evolution of the EU from its early stages to the current state of affairs. In this case, we need to employ the dichotomy past/future and, simultaneously, we face the tension between what the EU was/is and what the EU ought to be-and in light of this tension, we may build up our own critique. The most pressing questions in this context are: in which direction are we moving? How can we make sure that we are moving in the right direction? The third dimension of security is the popular dimension: people is an entity that the European project has had to come to terms with repeatedly, often to draw on its evocative force. As a result, inevitably we grapple with the dichotomy 'demos versus no demos' and the question is: what is constituent power? Is it necessary for transnational integration? What are the conditions that ensure a legitimate source of sovereign power? The fourth dimension is ontological: the nature of the EU. As competing theories of EU integration offer their own definition of the EU, our inquiry wavers between the two poles of 'federal State' versus 'loose international organization', with the several nuances that have been addressed by scholars belonging to different disciplines: what is the best interpretative scheme for the purposes of understanding EU integration? The fifth dimension is instead epistemic and addresses the problem of pluralism, as the co-existence of multiple rationalities and claims of authority within the same polity or legal system. When we ask what the best way to preserve the European project is, we must tackle the dichotomy 'one/many' and seek to ascertain how several rationalities can coexist in the same space. Finally, our last dimension, the semantic one, is based on the distinction between secure and insecure. In this scenario, our inquiry revolves around the question: what does it mean to be secure? How can a polity be secure? The necessary implication here is that whoever leads the security discourse is also the master of a vocabulary of immediacy, urgency, threat, which leaves little space for reflection and negotiation. Importantly, security reveals its double-edged nature, as the presupposition for European integration, and simultaneously as a threat to its development, if pursued at all costs. 
Table 1.1 Security dimensions

\begin{tabular}{|c|c|c|c|}
\hline Dimension & $\begin{array}{l}\text { Conceptual } \\
\text { category }\end{array}$ & Dichotomy & Questions \\
\hline Spatial & Space & Inside/outside & $\begin{array}{l}\text { Who is the } \\
\text { Other? Where } \\
\text { is it located? }\end{array}$ \\
\hline Temporal & Time & Past/future & $\begin{array}{l}\text { In which } \\
\text { direction are } \\
\text { we moving? }\end{array}$ \\
\hline Popular & People & $\begin{array}{l}\text { Demos/no } \\
\text { demos }\end{array}$ & $\begin{array}{l}\text { What is } \\
\text { constituent } \\
\text { power? }\end{array}$ \\
\hline Ontological & $\begin{array}{l}\text { Nature of the } \\
\text { EU }\end{array}$ & $\begin{array}{l}\text { Federal State } \\
\text { versus loose } \\
\text { international } \\
\text { organization }\end{array}$ & $\begin{array}{l}\text { What is the } \\
\text { best } \\
\text { interpretative } \\
\text { scheme? }\end{array}$ \\
\hline Epistemic & Pluralism & One/many & $\begin{array}{l}\text { How should } \\
\text { multiple } \\
\text { rationalities } \\
\text { or claims of } \\
\text { authority } \\
\text { coexist? }\end{array}$ \\
\hline $\begin{array}{l}\text { Semantic or } \\
\text { reflexive }\end{array}$ & $\begin{array}{l}\text { Notion of } \\
\text { security }\end{array}$ & Secure/insecure & $\begin{array}{l}\text { What does it } \\
\text { mean to be } \\
\text { secure? How } \\
\text { to be secure } \\
\text { as a polity? }\end{array}$ \\
\hline
\end{tabular}

Source: Author's own.

The above dimensions lead to an overall inquiry into the ultimate question, which sums up all previous questions and analysis: why is European integration taking place? Why is the European project constantly expanding-embracing new areas of competence, encroaching upon State legislation, and physically including ever more territories. In order to answer this question, and examine how the security of the European project unfolds, we need to understand the language of crisis. 


\section{EU CONSTITUTIONALISM AND CRISIS: THE SECURITY AND FUNDAMENTAL RIGHTS DISCOURSES}

On no other occasion than during a crisis, is the nature of law, its limits and its normativity, in the spotlight. As Hamilton argued in The Federalist Papers, 'the circumstances that endanger the safety of nations are infinite'. ${ }^{107}$ The unprecedented set of events in the first two decades of the twenty-first century have shattered the dream of a progressive, unstoppable, and inevitable 'integration through law'. The liberaldemocratic credentials of the European project, those very same credentials that were supposed to support and promote its expansion by establishing an institutional, socio-cultural and economic substrate of values, practices and interactive networks at the transnational level, currently seem to offer contradictory solutions to the crisis. Once again, as in a not-so-remote past:

the Europe of commerce and freedom - where money fled from the constraints of national frontiers, and individuals refused to fight for a cause they did not understand or left their country in search of a better lifestyle or more liberal government - was no less exposed to the risks of instability than had been Bonaparte's empire, as the general economic crisis that followed the end of the French wars in 1815 was soon to show. ${ }^{108}$

What is interesting in the development of European integration, of its configuration either in terms of international law or in terms of European constitutionalism (in its various guises), is the mind-frame of crisis that has accompanied it from its very beginning. After all, the EEC/EC/EU was born out of crisis (the Second World War) precisely in order to prevent inter-State war from happening again. In addition, the EU has faced crisis during its evolution, from the crisis of the empty chair, to the 1970s oil and terrorism crisis, the fall of the Berlin Wall, the postMaastricht crisis, the rejection of the referenda in France and the Netherlands, the economic and financial crisis, the Ukraine crisis, the

107 'It is impossible to foresee or to define the extent and variety of national exigencies, and the correspondent extent and variety of the means which may be necessary to satisfy them.' Therefore 'no constitutional shackles can wisely be imposed on the power to which the care of it is committed'. See C. Rossiter (ed.) The Federalist Papers (New American Library 1961) No. 23 p. 153 (Hamilton). 108 See (referring to 19th century Europe) B. Fontana, 'The Napoleonic Empire and the Europe of Nations' in A. Pagden, The Idea of Europe - from Antiquity to the European Union (CUP 2002) 116, 126-27. 
refugee and terrorism crisis, the rule of law crisis in Central and Eastern Europe and the Brexit crisis. Each crisis has marked crucial periods of European integration and has generated responses-no matter how (in)effective. These responses were demanded by the need to secure the European project, namely to ensure its continuity and stability in the face of internal and/or external threats. As will be shown in the next chapters, crisis and security are thus mutually reinforcing concepts: crisis generates security measures, and yet security measures themselves lay the conditions that determine the crisis. This circular process is fostered by a potential vacuum in the popular foundations of the European project. Every time the people have been evoked, either as constituent power, or as circulating citizens within the internal market, or as masses of refugees escaping war or famine, the European Union has been called upon to put in practice its liberal democratic ethos - to little avail. One reason for this is that the idea of 'people', recalled by the Treaties and the case-law of the CJEU, is problematic. As Lindahl observes, there exists 'a fundamental passivity at the heart of political community: instead of initiating, the collective is initiated by a constituent power'. ${ }^{109}$ We will come back to this question in the next chapter.

We have already observed that the dominant narrative among scholars and practitioners is that fundamental rights provisions were not present at the beginning of the process of European integration, and that the CJEU developed a jurisprudence of fundamental rights in response to the challenges brought by some relevant domestic constitutional courts, notably the German and Italian. According to this progressivist narrative, this original vocation of the EU would currently be under threat. In reality, this narrative-itself informed by the meta-rationale of security-is constrained by its ideological premises, as it reflects a mind-frame inherited from the Enlightenment: the idea that we witness a move from an arche, a more or less fuzzy origin towards an ever brighter future, a telos, which should be pursued relentlessly, because of its intrinsic value. ${ }^{110}$ In this sense, 'a continued development of the Union remains imperative' and 'the consolidation of the Union's shape ... will allow for politically promising solutions, which take into account the

109 H. Lindahl, 'The Paradox of Constituent Power: The Ambiguous SelfConstitution of the European Union' (2007) 20 Ratio Juris 485, 495.

110 See e.g. I. Kant, 'Idea for a Universal History with a Cosmopolitan Purpose' in I. Kant, Political Writings (CUP 1991) 41; A. Smith, An Inquiry into the Nature and Causes of the Wealth of Nations (The University of Chicago Press 1977 [1776]). 
Union's uniqueness'. ${ }^{111}$ This is a strong narrative, one in which no alternatives to how the EU is being constructed exist: 'the only way out of this present crisis is to have more Europe, not less Europe ... we think the euro is irreversible ... [w]ithin our mandate, the ECB is ready to do whatever it takes to preserve the euro. And believe me, it will be enough'. ${ }^{112}$

To this narrative, a counter-narrative is opposed, one that resorts to the eschatological imagery of end, disintegration. ${ }^{113}$ Yet, this narrative, too, is constrained by the languages of crisis and security: '[w]ithin this radius of the established oecumene, a multitude of crises may occur and seriously challenge the stability of the oecumenic whole. ... any thrust to intelligibility and orientation becomes lost and all syntheses of meaning disperse like airy clouds immersed in cosmic winds'. ${ }^{114}$ Whatever the perspective taken, the language of crisis and security is taken as granted, assuming that there would be a proper course of historical events, which includes 'how things should be', and, opposed to that, a set of more or less pronounced, and more or less evitable, deviations from such a course. In other words, such language is often employed to emphasise the discrepancy between 'the real' and what erroneously departs from 'the real', without questioning whether employing that language is adequate, in the first place. ${ }^{115}$ Narratives may be thus enclosed in their own conceptual frames, and 'crisis' may be reduced to a 'blind spot', an observation that produces meaning, instead of being, itself, a condition to be observed-and questioned. ${ }^{116}$ Why do theories of European integration, willingly or unwillingly, operate within the framework of security?

In fact, both the security meta-rationale and the image of crisis have been influenced by a peculiar understanding of the European liberal project-one which is deeply indebted to neoliberal approaches emerged

111 A. Von Bogdandy, 'The European Union as a Supranational Federation: A Conceptual Attempt in the Light of the Amsterdam Treaty' (2000) 6 Columbia Journal of European Law 27, 53-54.

112 Speech by Mario Draghi, President of the European Central Bank, at the Global Investment Conference, London, 26 July 2012, at http://www.ecb. europa.eu/press/key/date/2012/html/sp120726.en.html.

113 This counter-narrative may be, consciously or unconsciously, indebted to Heideggerian thought. See e.g. J. Wolfe, Heidegger's Escathology: Theological Horizons in Martin Heidegger's Early Work (OUP 2013) esp. 116-35.

114 J. Clam, 'What is A Crisis?' in P. Kjaer, G. Teubner, A. Febbrajo (eds.) The Financial Crisis in Constitutional Perspective - The Dark Side of Functional Differentiation (Hart 2011) 189, 217.

115 J. Roitman, Anti-crisis (Duke University Press 2014) 11-14.

116 Ibid. 39. 
in the post-war era. This is the 'paternalistic missionarism' of the liberal age. Post-war neoliberalism has taken it upon itself to promote the welfare of society and represent its universal aspirations, in line with classical liberal ideals. As is well-known, one of its main claims is that 'the progressive intensification of the division of labor is possible only in a society in which there is an assurance of lasting peace. Only under the shelter of such security, can the division of labor develop'. ${ }^{117}$ A neoliberal society is the only guarantee for progress, because 'interstate federalism' 'would do away with the impediments as to the movement of men, goods and capital between the states' and 'would render possible the creation of common rules of law, a uniform monetary system, and common control of communications'.118 Inter-state harmony of interests could only be achieved within a framework of international security, and this necessity is precisely what old nineteenth century liberalism had failed to grasp. ${ }^{119}$ Thus, although the overarching ideal of security had not yet turned into an all-encompassing meta-rationale, it was already present in the elaboration of political thought by the international élite of the early years.

How could it be otherwise, in the aftermath of the devastating world conflict? In a typically Kantian style, 'the main purpose of interstate federation is to secure peace', and the economic elements of such federation, namely a common fiscal and monetary policy, would be essential for its development. ${ }^{120}$ Of course, diversity must be ensured, and agreement ought to be allowed only on some minimal core values, as aiming for a more comprehensive form of agreement would foster dictatorial governments. However, ultimately neoliberalism recognizes that 'a national monetary policy which was predominantly guided by the economic and financial conditions of the individual state would inevitably lead to the disruption of the universal monetary system'.121 The main dilemma facing this strategic vision is that a project's unyielding perseverance in pursuing a specific goal at all costs may impair the very ideal from which that project is inspired. As will be explained in the next

117 L. Von Mises, Liberalism in the Classical Tradition (Cobden Press/The Foundation for Economic Education 2002) 25.

118 F. A. Hayek, 'The Economic Conditions of Interstate Federalism' in F. A. Hayek, Individualism and Economic Order (The University of Chicago Press 1948) 255.

119 Ibid. 270.

120 Ibid. $255-56$.

121 Ibid. 260. 
chapters, plenty of contradictions may be detected in the process of European integration.

Yet, in light of what we have observed above, why should we still be concerned about the security of the European project? And how can we secure normative grounds for our very critique? ${ }^{122}$ One important starting point is the re-elaboration of the idea of 'The People' as constituent power (the popular dimension, as outlined in Table 1.1 above). Any discussion about constituent power is always a discussion about the representation of something - and the process through which this representation takes place. Whatever was constituted at any given moment is always already presented as constituted every time its existence comes to the fore for the performance of a political function. ${ }^{123}$ If we adopt a dynamic view of constitutionalism as a process, then a staple of the EU self-identification as a polity must be its concern for the conditions under which such a process is sustainable. ${ }^{124}$ Yet, constitutionalism's dynamic nature can only be fully grasped through the identification of discursive practices, in the sense of all kinds of linguistically mediated practices (such as writing, speech, images), which social actors draw upon in their constant role of producers and interpreters of meaning. As meanings are endlessly created and re-shaped, struggles take place over them, in particular over the way fluctuating meanings may be crystallised. ${ }^{125}$ Yet,

122 After all, for several contemporary thinkers, the crisis of modernity is brought about both by the dissonance between what the reality is and what the reality ought to be, and by the need to secure the grounds for a critique of reality. See J. Habermas, The Philosophical Discourse of Modernity - Twelve Lectures (Polity Press 1987).

123 'The notions of constitution and constitutionalism ... are unarguably bound up with ... the mutual articulation of law and politics. ...', so that 'constitutional law is recursively involved in both the presentation and the representation of the polity' and 'there can be no polity without a constitutional discourse'. See N. Walker, 'The EU and the WTO: Constitutionalism in a New Key' in G. De Búrca, J. Scott (eds.), The EU and the WTO - Legal and Constitutional Issues (Hart 2001) 31, 34.

124 'reflexive constitutionalism should be capable of persuasively disseminating the idea that what binds the wider political community is no more and no less than the shared pragmatic desire to identify and secure whatever may be in the collective interest, including the conditions under which other and more intimate levels of political community or common action ... can thrive and interact in a just and well-coordinated manner'. See N. Walker, 'EU Constitutionalism and New Governance' in G. de Búrca, J. Scott (eds.), Law and New Governance in the EU and the US (Hart 2006) 15, 36.

125 M. Jörgensen, L. J. Phillips, Discourse Analysis as Theory and Method (SAGE Publications 2002) 24-29. 
meanings can only be crystallised through political acts of inclusion and exclusion and, importantly, discursive practices, although ambiguous and incomplete, may have sometimes constitutive effects, i.e. they may alter the surrounding reality. ${ }^{126}$ Power plays an important role in the formation and crystallization of meanings. It emerges neither as a reified relation of dominance, nor as a capacity to act, but as a complex and contingent relation between forces, as a web of discourses shaping the identities, capacities and interactions of the social actors themselves: in other words, power and discourse are mutually constitutive. ${ }^{127}$

From this angle, the idea of 'discursive constituent power' should be taken more seriously. Discursive constituent power is bound up with the process of constitutionalisation, whereby a polity comes into being. Through the configuration of constituent power in discursive terms, the EU's reliance on security and fundamental rights as discourses of power can be examined much more deeply. This is the topic of the next chapter. The following areas of EU law will be particularly relevant for our discussion of the security and fundamental rights discourses: AFSJ; citizenship/free movement; and the Eurozone reformed legislation.

\section{CONCLUSIONS}

The complex nature of European integration has made it very difficult to elaborate a commonly agreed definition of the EU machinery, encompassing its multiple facets. Often the degree of federalism and of democracy are points of contention in academic debates. A rich variety of paradigms and schemes of interpretation have been elaborated. However, while State-centric approaches do not capture the relevance of the constitutional moves made by the CJEU and other EU organs, federalist theories are not able to offer an accurate picture of the EU transnational process of integration. In this sense, the heterarchical paradigm seems more suitable and effective. What is missing in these efforts is a more careful look at the reasons behind the European liberal project and, simultaneously, the academic commitment to it. Security as a metarationale, broadly including all fields of EU law, and articulated through security and fundamental rights as discourses of power, lies at the heart of EU constitutionalism. Concern for security is intertwined with the

\footnotetext{
126 Ibid. 36-37.
}

127 J. Torfing, 'Discourse Theory: Achievements, Arguments, and Challenges' in D. Howarth, J. Torfing (eds.) Discourse Theory in European Politics: Identity, Policy and Governance (Palgrave Macmillan 2005) 1, 7-8. 
language of crisis and, while being the motor of EU integration, is characterized by contradictions and ambiguities, which have been enhanced by recent events. Looking at the six dimensions of securityspatial, temporal, popular, ontological, epistemic, semantic/reflexivewill allow us to unravel such ambiguities and understand the implications of our own commitment to the European project. 